\title{
RANCANG BANGUN DOCUMENT MANAGEMENT SYSTEM
}

\section{UNTUK MENGELOLA DOKUMEN STANDART OPERATIONAL PROCEDURE}

\author{
I Putu Susila Handika1, I Gede Totok Suryawan² \\ ${ }^{1,2}$ Program Studi Teknik Informatika, STIMIK STIKOM Indonesia \\ Email: ${ }^{1}$ susilaandika@gmail.com, ${ }^{2}$ totok.suryawan@gmail.com
}

(Naskah masuk: 14 Mei 2017, diterima untuk diterbitkan: 20 September 2017)

\begin{abstract}
Abstrak
Standart Operational Procedure (SOP) merupakan salah satu dokumen penting pada sebuah perusahaan karena berguna untuk meningkatkan mutu perusahaan. PT. Global Retailindo Pratama merupakan salah perusahaan yang bergerak dibidang retail yang menggunakan standart management mutu ISO 9001:2008. Saat ini pengelolaan dokumen SOP pada PT. Global Retailindo Pratama masih menggunakan cara tradisional. Cara tradisional tersebut menimbulkan beberapa masalah diantaranya adalah proses pencarian dan proses distribusi dokumen membutuhkan waktu yang cukup lama. Tujuan dari penelitian ini adalah merancang dan membangun Document Management System untuk mengelola dokumen SOP. Model pengembangan sistem yang digunakan pada penelitian ini adalah model prototyping. Aplikasi ini dibangun berbasis web dengan PHP sebagai bahasa pemrogrammannya. Pengujian aplikasi menggunakan Blak Box Testing dan Usability Testing menunjukkan bahwa aplikasi Document Management System dapat berjalan sesuai dengan kebutuhan dan dapat digunakan dengan mudah sehingga proses pengelolaan dokumen SOP menjadi lebih cepat.
\end{abstract}

Kata kunci: Document Management System, Standart Operational Procedure, Sistem Informasi, PHP.

\begin{abstract}
Standard Operational Procedure (SOP) is one important document in a company because it is useful to improve the quality of the company. PT. Global Retailindo Pratama is one of the companies engaged in retail that using standard of quality management ISO 9001: 2008. Currently the management of SOP documents at PT. Global Retailindo Pratama still use manual way. Manual way cause some problems such as the search process and document distribution process takes quite a long time. This research aims to design and build Document Management System to manage SOP documents. The system development model used in this research is prototyping model. This application is built in web-based with PHP as programming language. Testing the application using Blak Box Testing and Usability Testing shows that the Document Management System can run in accordance with the needs and can be used easily so that the process of document management SOP becomes faster.
\end{abstract}

Keywords: Document Management System, Standart Operational Procedure, Information System, PHP.

\section{PENDAHULUAN}

Kemunculan minimarket yang begitu banyak membuat persaingan semakin berat. Manajemen perusahaan harus memikirkan cara agar perusahaan dapat bersaing dengan perusahaan lainnya. Cara yang paling sering dilakukan adalah melalui harga, diferensiasi produk atau jasa, fleksibilitas, waktu pengiriman, dan mutu. Tidak dapat dipungkiri, mutu telah menjadi syarat utama bagi kesuksesan bisnis. Dalam hal ini, mutu yang dimaksud adalah produk yang dijual serta pelayanan kepada pelanggan. Banyak dampak positif yang dapat didapat jika manajemen memberikan perhatian penuh kepada mutu, salah satu yang paling penting adalah kepuasan pelanggan.

Salah satu cara meningkatkan mutu adalah dengan menerapkan suatu standar manajemen mutu dalam perusahaan (Santosa, dkk, 2013). PT. Global Retailindo Pratama (Minimart) merupakan salah satu perusahaan retail di Bali. Salah satu standar manajemen mutu yang digunakan pada perusahaan ini adalah International Organization for Standardization (ISO) 9001:2008. PT. Global Retailindo Pratama (Minimart) memiliki 8 departemen, 180 toko yang berada di Bali, dan 2 toko berada di Lombok. Saat ini penyimpanan dokumen Standart Operational Procedure pada perusahaan ini masih menggunakan cara tradisional yaitu menyimpan pada map dan diletakkan pada lemari arsip. Cara tradisional ini menimbulkan permasalahan ketika dokumen SOP tersebut harus dikirimkan ke masing-masing toko. Proses pengiriman dokumen jadi terhambat karena lokasi toko yang jauh dari kantor pusat. Selain itu proses pencarian dokumen juga kurang optimal karena dokumen SOP yang disimpan terlalu banyak dan lokasi penyimpanan yang tidak memadai.

Untuk mengatasi permasalahan tersebut, diperlukan sebuah sistem yang dikenal sebagai Document Management System (DMS). Dengan 
DMS, dokumen-dokumen kertas akan dikonversi menjadi bentuk digital sehingga proses ditribusi dokumen SOP menjadi lebih cepat dan mudah untuk dilakukan. Selain itu proses pencarian akan menjadi optimal karena user hanya perlu mengetik nama dokumen untuk melakukan proses pencarian. Dengan adanya aplikasi DMS, kebijakan keamanan dapat diterapkan dalam manajemen dokumen SOP melalui pengaturan hak akses untuk setiap pengguna.

Pengembangan sistem dalam penelitian ini menggunakan PHP dan SQL Server Express 2008 sebagai penyimpanan data. Bahasa pemrograman PHP digunakan pada penelitian ini karena PHP memiliki beberapa kelebihan yaiut: (1) PHP mudah dibuat dan memiliki kecepatan yang tinggi. (2) PHP dapat dijalankan di berbagai macam sistem operasi baik itu Windows, MAC, ataupun linux. (3) PHP diedarkan secara gratis. (4) PHP termasuk dalam server-side programming (Aggaeni \& Sujatmiko, 2013). SQL Server Express 2008 dipilih karena selain DBMS tersebut gratis, SQL Server Express 2008 mendukung Extended Stored Procedure yang dapat mempercepat proses pengolahan data (Pramana dkk, 2017).

\section{METODE PROTOTYPING}

Metode pengembangan perangkat lunak dipilih berdasarkan sifat aplikasi dan waktu yang diberikan untuk menyelesaikan aplikasi tersebut. Terdapat beberapa metode yang sering digunakan untuk pengembangan perangkat lunak, salah satunya adalah metode prototyping. Metode prototyping merupakan sebuah metode yang memiliki sifat berulang pada saat pembuatan desain aplikasi (Nugroho dkk, 2010). Pada proses perulangan, perancang hanya membuat rancangan sementara yang berfokus pada kebutuhan user.

Gambar 1 menunjukkan proses rancang bangun document management system untuk mengelola standart operational procedure di PT. Global Retailindo Pratama. Pada tahap pertama, pengembang akan mengumpulkan semua informasi yang mendukung pengembangan sistem. Setelah mengumpulkan informasi dari user, tahap kedua adalah pembuatan desain sistem. Output dari proses desain sistem adalah dokumentasi desain yang berupa use case, Data Flow Diagram (DFD), Conceptual Data Model (CDM), dan Pysical Data Model (PDM). Tahap ketiga adalah pembuatan prototipe sistem. Prototipe dibuat berdasarkan kebutuhan dan desain yang telah disetujui. Selanjutnya, prototipe tersebut akan dievaluasi oleh user. Jika terdapat evaluasi dari user, proses akan diulang sampai seluruh prototipe diterima oleh user. Tahap keempat adalah pembuatan aplikasi yang dilanjutkan dengan proses pengujian. Setelah aplikasi berjalan sesuai dengan kebutuhan, tahap terakhir adalah melakukan pemeliharaan terhadap aplikasi tersebut.

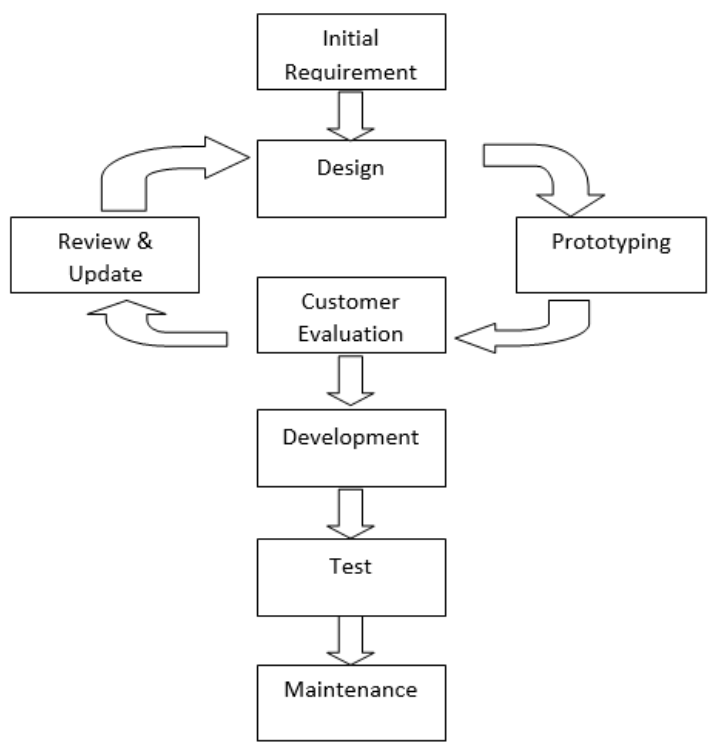

Gambar 1. Metode Prototyping

\section{ANALISIS KEBUTUHAN}

Analisis kebutuhan bertujuan untuk menggali informasi sehingga didapat kebutuhan fungsional dari Document Management System yang akan dibuat. Analisis kebutuhan didapat dengan cara melakukan wawancara langsung dengan user yang terlibat pada proses bisnis. Tabel 1 menunjukkan kebutuhan fungsional yang didapat dari hasil wawancara.

Tabel 1. Kebutuhan Fungsional

\begin{tabular}{|c|c|}
\hline No & Requirement \\
\hline 1 & $\begin{array}{l}\text { User hanya bisa melihat SOP. Tidak boleh print } \\
\text { dan download SOP }\end{array}$ \\
\hline 2 & $\begin{array}{l}\text { User yang berhak upload SOP adalah Document } \\
\text { Control (DCR) }\end{array}$ \\
\hline 3 & Sistem dapat memberikan info jika ada SOP baru \\
\hline 4 & $\begin{array}{l}\text { User diperbolehkan melihat SOP departemen } \\
\text { lainnya jika dokumen tersebut berhubungan }\end{array}$ \\
\hline 5 & $\begin{array}{l}\text { Sistem dapat menampilkan data } \text { user yang sudah } \\
\text { menerima SOP }\end{array}$ \\
\hline 6 & $\begin{array}{l}\text { User yang harus melakukan konfirmasi } \\
\text { penerimaan SOP adalah: } \\
\text { - Kepala departemen jika SOP ditujukan } \\
\text { untuk departemen selain departemen } \\
\text { Operational } \\
\text { Store Supervisor, Assistant Area Manager } \\
\text { (AAM) jika dokumen ditujukan untuk } \\
\text { departemen Operational } \\
\text { Staff tidak dapat melihat SOP jika SOP tersebut } \\
\text { tidak disetujui oleh kepala departemen. }\end{array}$ \\
\hline 7 & $\begin{array}{l}\text { Sistem dapat menampilkan laporan user yang } \\
\text { melakukan konfirmasi untuk setiap SOP baru } \\
\text { yang telah diterbitkan }\end{array}$ \\
\hline 8 & $\begin{array}{l}\text { Sistem dapat menampilkan laporan apa saja yang } \\
\text { telah diterbitkan }\end{array}$ \\
\hline 9 & $\begin{array}{l}\text { Sistem dapat mengirim email jika ada SOP baru } \\
\text { yang diterbitkan }\end{array}$ \\
\hline
\end{tabular}




\section{DESAIN SISTEM}

Sesuai dengan analisis yang telah dibuat, dapat dibuat desain sistem seperti berikut.

\subsection{Use Case}

Document Management System untuk mengelola Standart Operational Procedure (SOP) memiliki empat user yang dibagi menjadi administrator, document control, manager, dan staff. Keempat user tersebut memiliki hak akses yang berbeda-beda. User administrator merupakan user tertinggi pada sistem dimana user administrator memiliki hak untuk mengelola data user, mengelola hak akses tiap user, mengelola data SOP, serta melihat report. Gambar 2 menunjukkan use case untuk administrator.

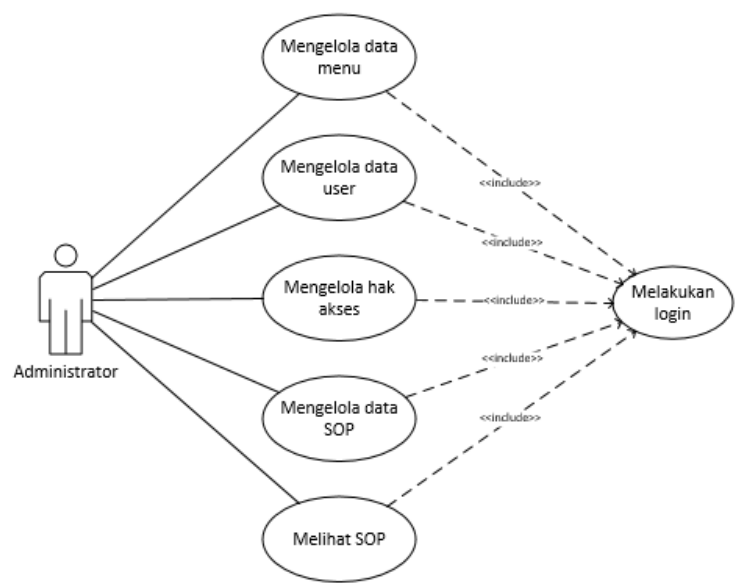

Gambar 2. Use Case Administrator

User document control adalah user yang bertugas untuk meng-upload dokumen SOP ke dalam sistem. Selain meng-upload dokumen, user document control dapat melihat dokumen SOP yang disediakan oleh sistem. Gambar 3 menunjukkan use case untuk document control.

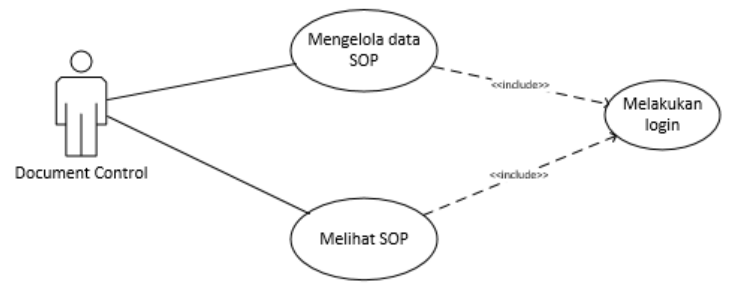

Gambar 3. Use Case Document Control

User manager adalah user yang bertugas untuk menyetujui dokumen yang telah di-upload oleh user document control dalam hal ini user yang dimaksud sebagai manager adalah kepala departemen, store supervisor, assistant area manager, dan assistant manager.

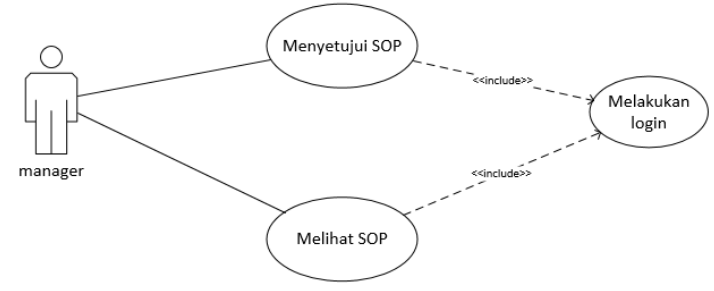

Gambar 4. Use Case Manager

Sesuai dengan analisis kebutuhan pada Tabel 1 , dokumen SOP yang telah di-upload tidak dapat dilihat oleh staff jika dokumen tersebut belum disetujui oleh kepala departemen. Gambar 4 menunjukkan use case untuk manager.

User staff merupakan user yang hanya dapat melihat dokumen SOP sesuai dengan departemen dan dokumen SOP terhubung dengan departemen-nya. Semua dokumen tersebut harus sudah disetujui oleh manager dari departemen masing-masing. Gambar 5 menunjukkan use case untuk staff.

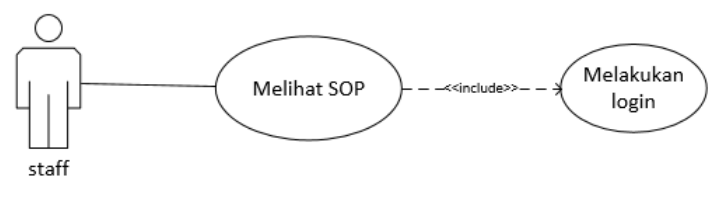

Gambar 5. Use Case Staff

\subsection{Data Flow Diagram (DFD)}

Data Flow Diagram (DFD) merupakan suatu model yang menggambarkan alur data sebuah sistem baik secara manual ataupun komputerisasi (Rismayani \& Sy, 2015). Entitas yang terhubung dengan aplikasi Document Management System antara lain adminstrator, document control, manager, dan staff. Entitas administrator adalah entitas yang dapat semua proses pada sistem. Entitas document control adalah entitas yang bertugas untuk mengelola dokumen SOP dan melihat SOP yang sudah diupload. Entitas manager adalah entitas yang bertugas menyetujui SOP yang telah di-upload oleh document control. Entitas staff adalah entitas yang hanya dapat melihat SOP yang telah disetujui oleh manager dari masing-masing departemen. Inputan data dari entitas administrator adalah data user, data sop, dan data hak akses. Output yang diterima oleh entitas administrator adalah info sop, info hak akses, serta info user. Inputan pada entitas document control adalah data sop dan Output yang didapat oleh entitas document control adalah info sop. Entitas manager hanya menginputkan data approval ke sistem dan mendapatkan info SOP sebagai Outputnya. Sedangkan entitas staff hanya menerima info SOP sebagai Output. Gambar 6 menunjukkan DFD level konteks aplikasi Document Management System. 


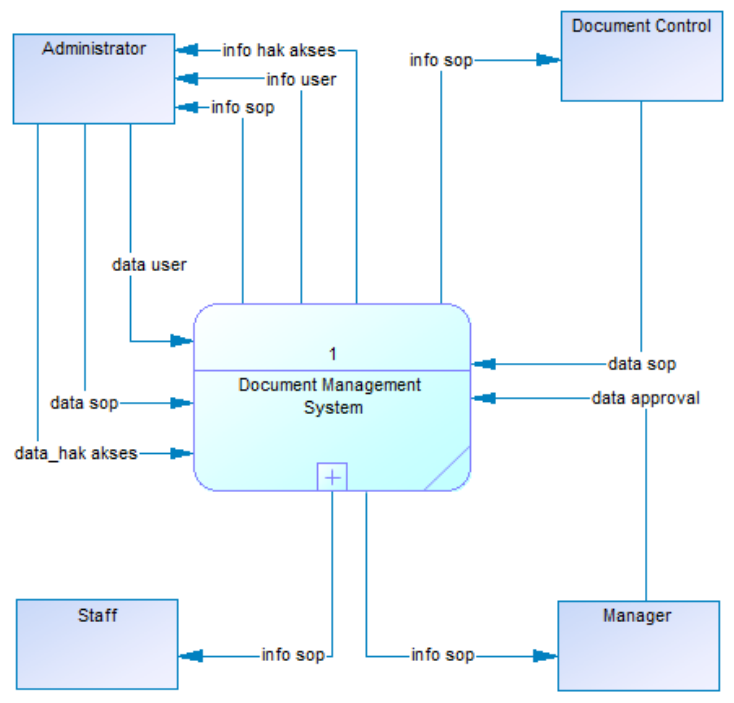

Gambar 7. DFD Level Konteks Document Managemen System. pada tingkat abstraksi, entitas yang saling berelasi dan mewakili data dari domain masalah (Ribeiro, Silva, \& Silva, 2015). Gambar 8 menunjukkan relasi antar tabel dalam aplikasi Document Management System.

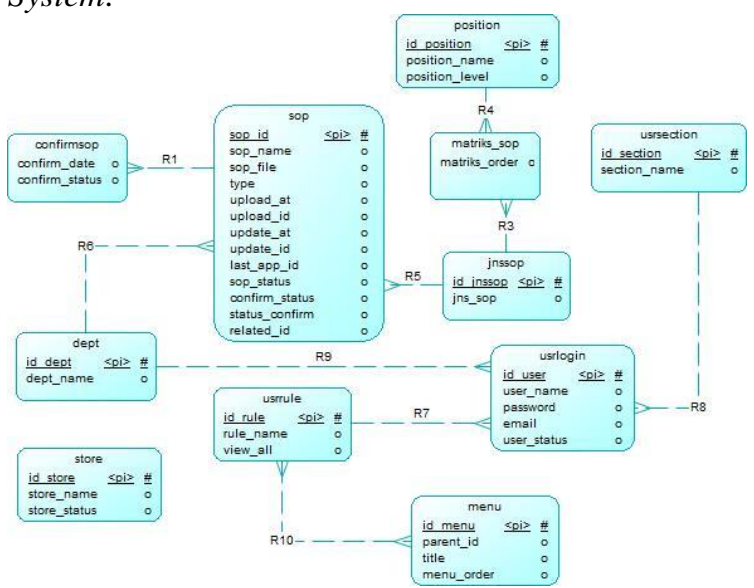

Gambar 8. Conceptual Data Model Document Management System.

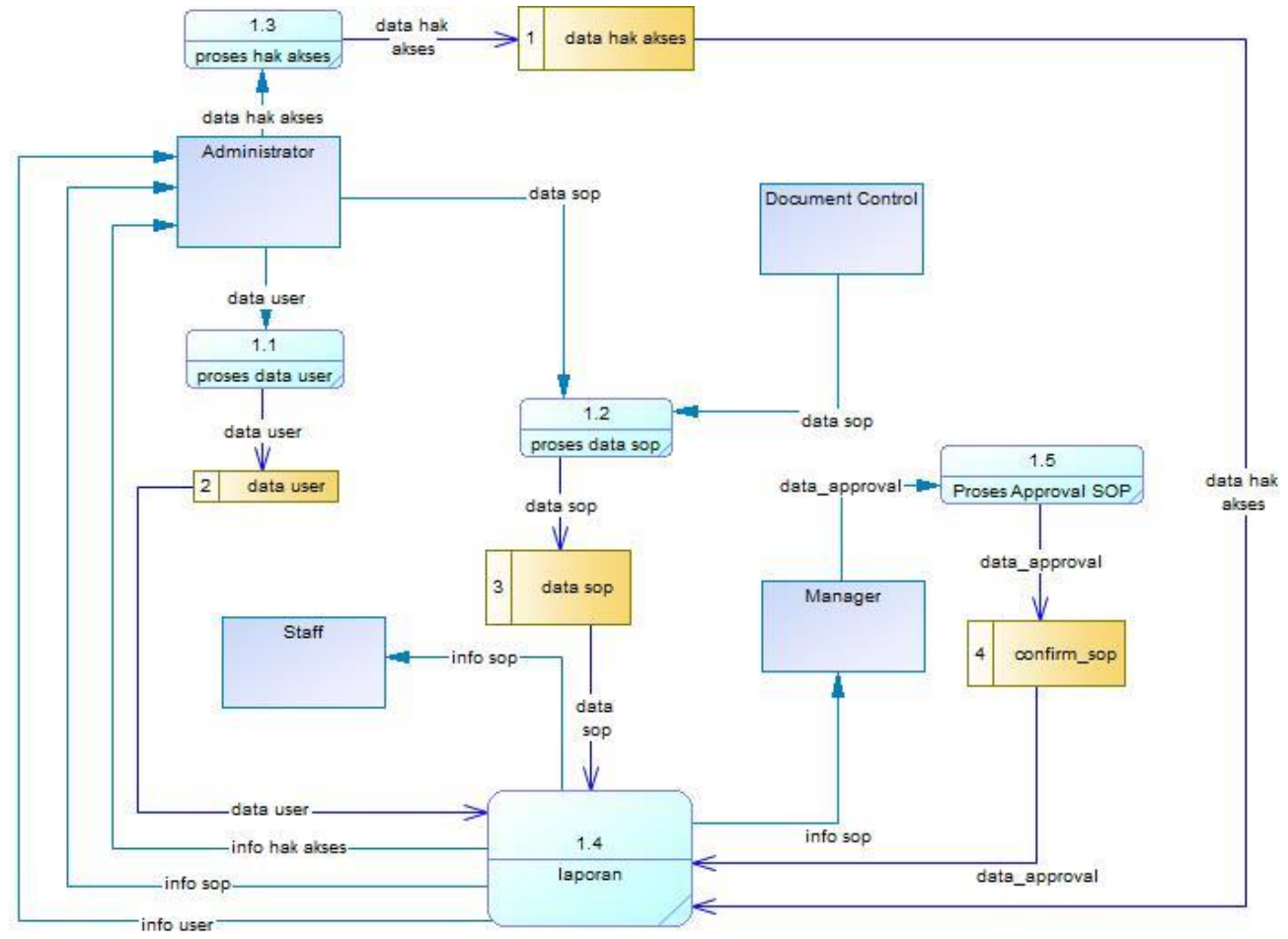

Gambar 6. DFD

DFD level konteks dapat didekomposisi menjadi DFD level 0. Pada DFD level 0 proses digambarkan lebih detail mulai dari proses untuk data user, proses untuk hak akses, proses untuk SOP serta laporan. Dalam DFD level 0 juga terlihat datasource yang digunakan dalam sistem. Gambar 7 menunjukkan DFD level 0 Document Management System.

\subsection{Conceptual Data Model}

Conceptual Data Model (CDM) merupakan sebuah model yang merepresentasikan informasi
Terdapat 11 tabel yang saling berelasi membentuk sebuah database. Tabel tersebut adalah tabel sop, position, confirmsop, matriks_sop, usrsection, jnssop, dept, usrlogin, usrrule, store, dan menu.

\section{HASIL DAN PEMBAHASAN}

\subsection{Aplikasi Document Management System}

Hasil dari tahap pengembangan Document Management System menggunakan bahasa 
pemrogramman PHP ditunjukkan pada Gambar 9 sampai dengan Gambar 11.

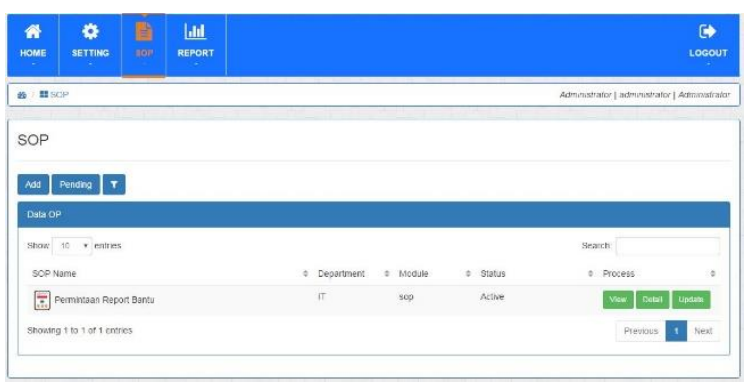

Gambar 9. Form List SOP.

Gambar 9 menunjukkan form list SOP. Semua dokumen yang telah diupload akan muncul pada form ini. Pada form list SOP user dapat melakukan proses melihat detail SOP seperti yang ditunjukkan oleh Gambar 10. Pada form detail SOP, user dapat melihat informasi yang dimiliki oleh dokumen SOP mulai dari nomer dokumen, nama dokumen, tanggal upload, identitas user yang meng-upload, tanggal perubahan dokumen, nomer revisi dokumen. Selain itu user juga dapat melihat dokumen SOP sesuai dengan yang diupload oleh document control.

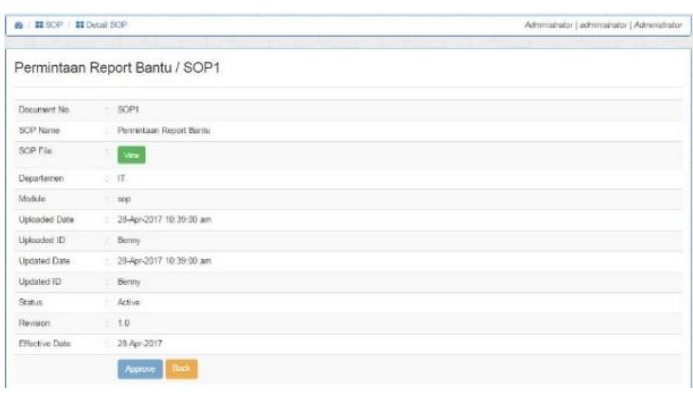

Gambar 10. Form Detail SOP.

Gambar 11 menunjukkan form untuk mengupload dokumen SOP. User yang berhak untuk masuk ke form upload SOP hanya document control dan administrator.

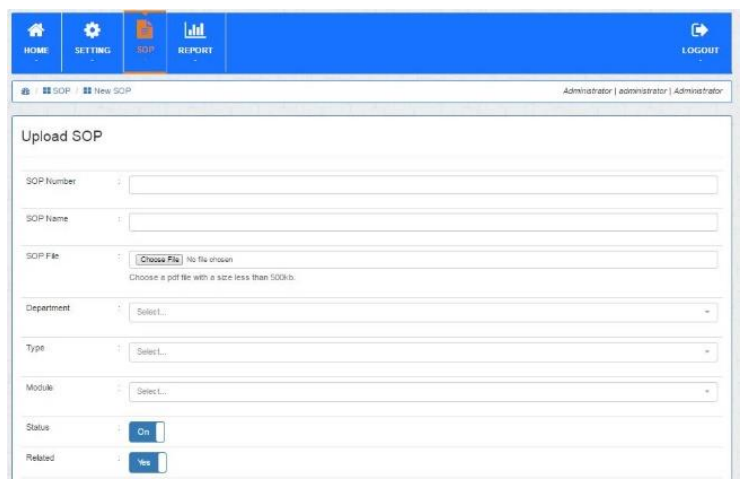

Gambar 11. Form Upload SOP.
Pada form upload SOP user dapat memberikan nama, memilih departemen, status, dll. Sesuai dengan kebutuhan yang didapat, sistem akan mengirimkan notifikasi berupa email kepada user manager sebagai pemberitahuan jika ada dokument baru yang harus disetujui.

\subsection{Pengujian Fungsional (Blackbox Testing)}

Pengujian fungsional sistem merupakan salah satu metode pengujian yang didasari oleh kebutuhan sistem. Tujuan dari pengujian black box adalah kebutuhan fungsional dapat berjalan dengan baik pada aplikasi Document Management System. Pengujian black box dilakukan dengan cara menjalankan modul-modul aplikasi Document Management System dihadapan user lalu memberikan status OK jika modul yang diujikan diterima oleh user. Tabel 2 menunjukan hasil pengujian fungsional (Black Box) Document Management System. Sesuai dengan hasil pengujian pada Tabel 2, semua fungsional mempunyai status OK dengan demikian dapat dikatakan sistem berfungsi dengan baik sesuai dengan requirement.

Tabel 2. Hasil Pengujian Fungsional (Black Box Testing)

\begin{tabular}{|c|c|c|}
\hline No & Requirement & Status \\
\hline 1 & $\begin{array}{l}\text { User hanya bisa melihat SOP. Tidak } \\
\text { boleh print dan download SOP }\end{array}$ & $\mathrm{OK}$ \\
\hline 2 & $\begin{array}{l}\text { User yang berhak upload SOP adalah } \\
\text { Document Control (DCR) }\end{array}$ & $\overline{\mathrm{OK}}$ \\
\hline 3 & $\begin{array}{l}\text { Sistem dapat memberikan info jika ada } \\
\text { SOP baru }\end{array}$ & OK \\
\hline 4 & $\begin{array}{l}\text { User diperbolehkan } \\
\text { departemen lainnya } \\
\text { tersebut berhubungan }\end{array}$ & $\overline{\mathrm{OK}}$ \\
\hline 5 & $\begin{array}{l}\text { Sistem dapat menampilkan data user } \\
\text { yang sudah menerima SOP }\end{array}$ & $\overline{\mathrm{OK}}$ \\
\hline 6 & 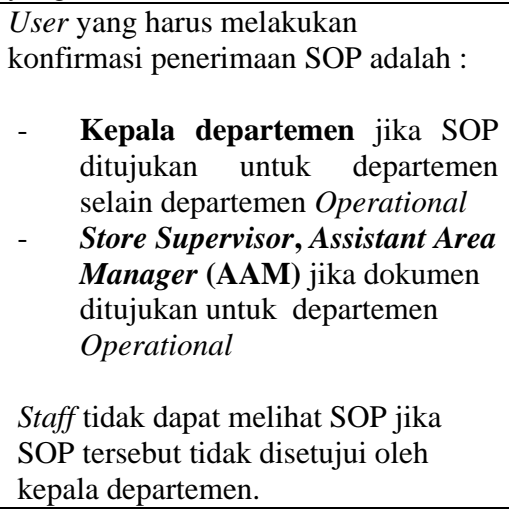 & OK \\
\hline 7 & $\begin{array}{l}\text { Sistem dapat menampilkan report user } \\
\text { yang melakukan konfirmasi untuk } \\
\text { setiap SOP baru yang telah diterbitkan }\end{array}$ & OK \\
\hline 8 & $\begin{array}{l}\text { Sistem dapat menampilkan report apa } \\
\text { saja yang telah diterbitkan }\end{array}$ & OK \\
\hline 9 & $\begin{array}{l}\text { Sistem dapat mengirim email jika ada } \\
\text { SOP baru yang diterbitkan }\end{array}$ & OK \\
\hline
\end{tabular}




\subsection{Usability Testing}

Usability Testing metode untuk menguji sebuah sistem dimana fokus dari pengujian ini adalah kenyamanan pada saat penggunaan sistem serta menjamin semua aspek dalam sistem dapat berjelan dengan baik. Salah satu metode untuk menguji usability testing adalah metode USE. Tiga aspek yang dicakup oleh metode USE adalah efisiensi, efektivitas, dan kepuasan (Rahadi, 2014). Terdapat 30 pertanyaan yang disediakan oleh metode USE untuk mengukur tingkat persetujuan user terhadap aplikasi yang telah dibuat. Point-point kuisioner pada metode USE adalah sebagai berikut (Aelani \& Falahah, 2012):

\section{Kegunaan}

1. Pekerjaan saya menjadi lebih efektif dengan adanya aplikasi ini.

2. Saya menjadi lebih produktif dengan adanya aplikasi ini.

3. Aplikasi ini berguna bagi saya.

4. Saya mendapatkan kontrol yang lebih dari aplikasi ini.

5. Saya dapat menyelesaikan hal-hal dengan lebih mudah.

6. Waktu yang saya gunakan untuk bekerja menjadi lebih hemat.

7. Kebutuhan saya terpenuhi dengan adanya aplikasi ini.

8. Semua yang saya harapkan dapat dilakukan oleh aplikasi ini.

\section{Kemudahan dalam penggunaan}

9. Aplikasi ini mudah digunakan.

10. Aplikasi ini mudah dimengerti.

11. Tampilannya menarik.

12. Langkah-langkah untuk mencapai tujuan sangat sedikit.

13. Kontennya fleksibel, sesuai dengan kebutuhan.

14. Saat menggunakan aplikasi ini, tidak perlu upaya yang lebih.

15. Tanpa instruksi tertulis, saya bisa menggunakannya.

16. Tampilannya konsisten.

17. Saya menyukai aplikasi ini.

18. Kesalahan dapat diselesaikan dengan cepat dan mudah.

19. Saya bisa menggunakan dengan sukses setiap saat.

\section{Kemudahan dalam pembelajaran}

20. Tidak membutuhkan waktu yang lama untuk mempelajari aplikasi ini.

21. Aplikasi ini mudah diingat.

22. Aplikasi ini mudah digunakan untuk pemula.
23. Saya dapat menggunakan aplikasi dengan terampil tanpa membutuhkan waktu yang lama.

\section{Kepuasan}

24. Saya puas dengan aplikasi ini.

25. Aplikasi ini sangat direkomendasikan kepada orang lain.

26. Sangat menyenangkan dalam menggunakan aplikasi ini.

27. Aplikasi ini bekerja seperti yang saya inginkan.

28. Aplikasi ini mengagumkan.

29. Aplikasi ini harus saya miliki.

30. Aplikasi ini nyaman digunakan.

Tabel 3 menunjukkan contoh tabel kuisioner usablity testing yang diberikan pada karyawan PT. Global Retailindo dengan rincian yang ditunjukan pada Tabel 4.

Tabel 3. Kuisioner usability testing .

\begin{tabular}{|c|c|c|c|c|c|c|c|c|c|}
\hline No & Pertanyaan & 1 & 2 & 3 & 4 & 5 & 6 & 7 & $\begin{array}{l}\mathbf{N} \\
\mathbf{A}\end{array}$ \\
\hline 1 & $\begin{array}{l}\text { Pekerjaan } \\
\text { saya menjadi } \\
\text { lebih efektif } \\
\text { dengan } \\
\text { adanya } \\
\text { aplikasi ini }\end{array}$ & & & & & & & & \\
\hline 2 & $\begin{array}{l}\text { Saya menjadi } \\
\text { lebih } \\
\text { produktif } \\
\text { dengan } \\
\text { adanya } \\
\text { aplikasi ini }\end{array}$ & & & & & & & & \\
\hline 3 & $\begin{array}{l}\text { Aplikasi ini } \\
\text { berguna bagi } \\
\text { saya }\end{array}$ & & & & & & & & \\
\hline$\ldots$ & $\cdots$ & & & & & & & & \\
\hline ... & $\ldots$ & & & & & & & & \\
\hline 28 & $\begin{array}{l}\text { Aplikasi ini } \\
\text { me- } \\
\text { ngagumkan }\end{array}$ & & & & & & & & \\
\hline 29 & $\begin{array}{l}\text { Aplikasi ini } \\
\text { harus saya } \\
\text { miliki }\end{array}$ & & & & & & & & \\
\hline 30 & $\begin{array}{l}\text { Aplikasi ini } \\
\text { nyaman } \\
\text { digunakan }\end{array}$ & & & & & & & & \\
\hline
\end{tabular}

Tabel 4. Pembagian Sampel.

\begin{tabular}{|l|l|}
\hline \multicolumn{1}{|c|}{ Objek } & Jumlah (Orang) \\
\hline Manager & 10 \\
\hline Staff Back Office & 10 \\
\hline Staff Toko & 100 \\
\hline Store Supervisor & 50 \\
\hline Assistant Area Manager & 5 \\
\hline
\end{tabular}


Setelah dilakukan pengujian usability testing, didapat hasil seperti yang ditunjukkan pada Gambar 12.

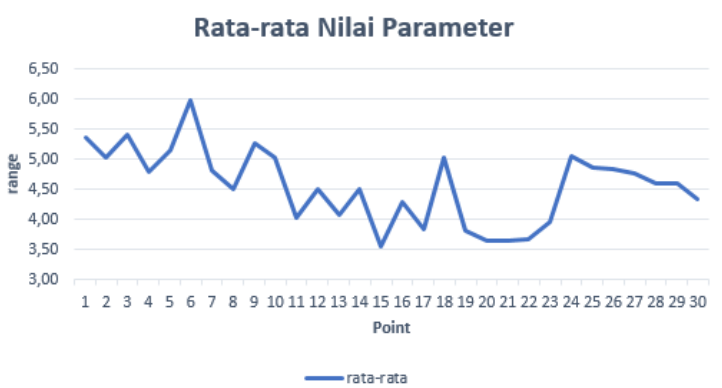

Gambar 12. Rata-rata Nilai Tiap Parameter.

Hasil pengolahan data pengujian ditemukan bahwa point yang mendapat nilai dibawah nilai tengah skala likert adalah point nomer $15,17,19,20$, 21,22, 23 dimana point 15,17 , dan 19 mengacu pada elemen ease of use dan point 20,21, 22, 23 mengacu pada elemen ease of learning. Temuan ini dapat disebabkan karena berbagai faktor dimana salah satu faktornya adalah tingkat pendidikan yang dimiliki oleh staff toko yang masih banyak berada pada level SMA. Sehingga kemampuan untuk mempelajari hal yang baru khusunya dalam bidang teknologi masih dibawah rata-rata. Kekurangan pada elemen ease of use dan ease of learning dapat diatasi dengan melakukan pelatihan dan pendampingan terhadap user yang menggunkaan aplikasi Document Managemnt System terutama staff toko. Dari keseluruhan rata-rata tiap pertanyaan menunjukkan hasil lebih dari nilai tengah slaka likert $1-7$ yang berarti secara garis besar, aplikasi Document Managemnt System dapat diterima dan dapat berjalan sesuai dengan kebutuhan user (Oktaviani, Widyawan, \& Hantono, 2014).

\section{KESIMPULAN DAN SARAN}

Berdasarkan penelitian yang telah dilakukan, aplikasi Document Management System dapat membantu pihak document control untuk mengelola dokumen Standart Operational Procedure di PT. Global Retailindo Pratama. Dengan adanya sistem, proses pendistribusian dokumen ke departemen dan seluruh toko menjadi lebih cepat karena dokumen tidak perlu dihantarkan ke departemen maupun toko tujuan. Dari hasil pengujian juga semua kebutuhan yang dianalisis di awal pengembangan sistem dapat diterima dengan baik dan dapat digunakan oleh user walaupun perlu pelatihan dan pendampingan terutama pada user staff toko. Untuk penelitian selanjutnya, diharapkan sistem dapat berjalan pada aplikasi mobile sehingga proses untuk melihat dokumen dapat dilakukan dimana saja.

\section{DAFTAR PUSTAKA}

AELANI, K., \& FALAHAH. (2012). Pengukuran Usability Sistem Menggunakan USE
Questionaire (Studi Kasus Aplikasi Perwalian Online STIMIK "AMIKBANDUNG"). Seminar Nasional Aplikasi Teknologi Informasi 2012 (SNATI 2012).

AGGAENI, P. A., \& SUJATMIKO, B. (2013). Sistem Informasi Tugas Akhir Berbasis Web(Studi Kasus D3 Manajemen Informatika TE FT Unesa). Jurnal Manajemen Informatika, 2, 37-45.

NUGROHO, A., BEEH, Y. R., \& ASTUNINGDYAS, H. (2010). Perancangan Aplikasi Rencana Anggaran Biaya (RAB) (Studi Kasus Pada Dinas Pekerjaan Umum Kota Salatiga). Jurnal Informatika, 10(1), $10-18$.

OKTAVIANI, T. W., WIDYAWAN, \& HANTONO, B. S. (2014). Perancangan User Interface Berbasis Web Untuk Home Automation Gateway Yang Berbasis IQRF TR53B. Seminar Nasional Teknologi Informasi Dan Komunikasi, 271-278.

PRAMANA, R., GUNAWAN, A., \& STYORINI, W. (2017). Sistem Informasi Pendeteksi Dini Banjir. Jurnal Aksara Elementer, 2(2).

RAHADI, D. R. (2014). Pengukuran Usability Sistem Menggunakan Use Questionnaire Pada Aplikasi Android. Jurnal Sistem Informasi, 6(1).

RIBEIRO, A., SILVA, A., \& SILVA, A. R. DA. (2015). Data Modeling and Data Analytics: A Survey from a Big Data Perspective. Journal of Software Engineering and Applications, $\quad$ 08(12),617. https://doi.org/10.4236/jsea.2015.812058

RISMAYANI, \& SY, H. (2015). Implementasi Manajemen Sistem Informasi Siaran Pada Radio Venus FM Makassar. Jurnal Sistem dan Informatika, $O(0)$.

SANTOSA, M. A. W., WIDHIAWATI, I. A. R., \& DIPUTRA, G. A. (2013). Penerapan Standar Sistem Manajemen Mutu (ISO) 9001:2008 Pada Kontraktor PT. Tunas Jaya Sanur. Jurnal Ilimiah Elektro Infrastruktur Teknik Sipil, 2, 1-6. 